\title{
Nonadenomatous nonencapsulated thymic parathyroid tissue concomitant with primary hyperparathyroidism due to ectopic parathyroid adenoma
}

\author{
Tecido tímico paratireoidiano não edematoso e não \\ encapsulado concomitante com hiperparatireoidismo \\ devido a adenoma paratireoidiano ectópico
}

Askin Gungunes', Mustafa Sahin', Salih Sinan Gultekin², Demet Yilmazer ${ }^{3}$, Alper Dilli ${ }^{4}$, Kemal Yandakci ${ }^{5}$, Mustafa Ozbek ${ }^{1}$, Erman Cakal' ${ }^{1}$, Tuncay Delibasi'

\section{SUMMARY}

Primary hyperparathyroidism due to ectopic parathyroid adenoma is not infrequent. Primary hyperparathyroidism caused by unusual thymic nonadenomatous nonencapsulated parathyroid tissue has been reported before. Both can cause unsuccessful neck explorations. Here we presented for the first time a patient with hyperparathyroidism due to ectopic parathyroid adenoma concomitant to the presence of thymic nonadenomatous nonencapsulated parathyroid tissue. Arq Bras Endocrinol Metab. 2013;57(9):739-42

\section{SUMÁRIO}

O hiperparatireodismo primário devido a adenoma ectópico paratireoidiano não é raro. 0 hiperparatireodismo primário causado por tecido tímico paratireoidiano não edematoso e não encapsulado incomum já foi relatado anteriormente. Ambos podem levar à exploração cervical malsucedida. Apresentamos aqui, pela primeira vez, uma paciente com hiperparatireoidismo decorrente de um adenoma paratireoidiano concomitante com a presença de tecido tímico paratireoidiano não edematoso e não encapsulado. Arq Bras Endocrinol Metab. 2013;57(9):739-42

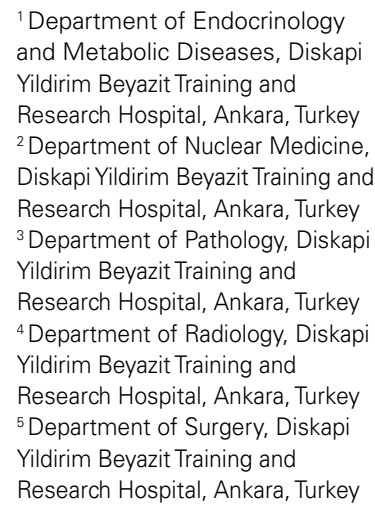

1 Department of Endocrinology and Metabolic Diseases, Diskapi Yildirim Beyazit Training and Research Hospital, Ankara, Turkey ${ }^{2}$ Department of Nuclear Medicine, Diskapi Yildirim Beyazit Training and Research Hospital, Ankara, Turkey ${ }^{3}$ Department of Pathology, Diskapi Yildirim Beyazit Training and Research Hospital, Ankara, Turkey ${ }^{4}$ Department of Radiology, Diskapi Yildirim Beyazit Training and Research Hospital, Ankara, Turkey ${ }^{5}$ Department of Surgery, Diskapi Yildirim Beyazit Training and Research Hospital, Ankara, Turkey

\section{Correspondence to:}

Askin Gungunes

Department of Endocrinology

and Metabolic Diseases,

Diskapi Yildirim Beyazit

Training and Research Hospital,

Ankara, Turkey

askn79@yahoo.com

Received on Oct/29/2012

Accepted on May/3/2013

\section{INTRODUCTION}

$\mathrm{M}$ inimally invasive parathyroidectomy is generally used for the treatment of primary hyperparathyroidism in patients with parathyroid adenoma ( 1 ). If there is doubt in localization, open bilateral neck exploration is considered the standard option (2). Ectopic parathyroid adenoma is a common cause of failed parathyroidectomies (3). Incidence of ectopic parathyroid glands is up to $10 \%$, and the majority of them are inferior parathyroid glands because of abnormal migration during embryogenesis (4).

Embryologically, the thymus migrates caudally escorted by the inferior parathyroid glands. Parathyroid tissue may descend up to thymus. Primary hyperpara- thyroidism due to nonadenomatous unencapsulated parathyroid tissue has been previously reported (5). Here, we present, for the first time, an extremely rare condition of primary hyperparathyroidism. To our knowledge, this is the first case regarding the coexistence of thymic nonadenomatous nonencapsulated parathyroid tissue and an ectopic parathyroid adenoma in the tracheoesophageal groove.

\section{CASE REPORT}

A 20-year-old female patient presented long-term bone pain and fatigue. The patient's serum calcium was 12.5 $\mathrm{mg} / \mathrm{dL}$ (normal range: $8.6-10.3 \mathrm{mg} / \mathrm{dL}$ ), phospho- 
rus was $1.5 \mathrm{mg} / \mathrm{dL}$ (normal range: $2.5-4.5 \mathrm{mg} / \mathrm{dL}$ ), parathyroid hormone was $464 \mathrm{pg} / \mathrm{mL}$ (normal range: 11-68 pg/mL), 25-hydroxy vitamin D was $9.6 \mathrm{ng} / \mathrm{ml}$ (normal range: $25-80 \mathrm{ng} / \mathrm{mL}$ ), 24 hour calcium excretion in urine was $59.29 \mathrm{mEq} /$ day (normal range: $5-15 \mathrm{mEq} /$ day). Neck ultrasonography showed no lesion consistent with a parathyroid adenoma. Persistent pathological activity was identified on both sides of the lower pole of thyroid lobe by ${ }^{99 \mathrm{~m} T c}$-sestamibi parathyroid scintigraphy (Figure 1A). The patient then underwent surgical bilateral neck exploration. After parathyroid exploration, no parathyroid adenoma was found. After partial thymectomy, frozen sections were obtained. In the frozen section, cellular parathyroid tissue was observed in the thymus tissue. The thyroid gland was not removed during surgery. Thymic nonadenomatous nonencapsulated parathyroid tissue was reported in the postoperative pathology results (Figure 2). Postoperative serum calcium $(11.0 \mathrm{mg} / \mathrm{dL})$ and parathyroid hormone $(293 \mathrm{pg} / \mathrm{mL})$ levels decreased, but still remained high. Postoperative scintigraphic images were taken 3 months after the initial surgery. Postoperative scintigraphic examination revealed persistent pathological activity around to right lower pole of the thyroid gland. Pathological activity on the left inferior lobe disappeared (Figure 1B). Neck magnetic resonance imaging (MRI) showed a $2 \times 1.5 \mathrm{~cm}$ nodular lesion consistent with parathyroid adenoma, which was diffusely stained in the contrast series. The nodular lesion was located in the right bottom section of the neck. The patient underwent reoperative neck surgery. In the second operation, a gamma probe was used. With the aid of the gamma probe, the lower right parathyroid gland was resected from an ectopic location within the tracheoesophageal groove. The pathology result was consistent with parathyroid adenoma. Vitamin D and calcium replacement were given to the patient due to postoperative hungry bone syndrome. Serum calcium levels returned to normal several months after surgery.

\section{DISCUSSION}

The majority of patients $(80 \%-85 \%)$ with primary hyperparathyroidism have a solitary adenoma (6). In $80 \%-85 \%$ of these patients, the adenomas are located in typical anatomical localizations, and in $15 \%-20 \%$ of the cases they are ectopic (7). Superior parathyroid glands along with the thyroid glands lateral lobes develop from the $4^{\text {th }}$ branchial pouch, whereas inferior glands, along with the thymus, develop from the $3^{\text {rd }}$ branchial pouch and move caudally to their normal anatomical location (8). During this caudal migration, any abnormality may result in the ectopic placement of these glands. There are two types of ectopic localization. The first type is due to mechanical factors, and occur as a result of large adenomas. This is usually observed in the superior glands. In the second type, the ectopic location is due to abnormal organogenesis. This second type is usually observed in the inferior glands (9). Superior ectopic glands may be located in the retropharyngeal, retroesophageal and tracheoesophageal regions. Inferior ectopic glands may be retroesophageal, intrathyroidal, intrathymic regions, within the carotid sheath, thyrothymic ligament, within the aortopulmonary window in the mediastinum, and within the pericardium (9).

In our case, the patient had a solitary adenoma located ectopically within the tracheoesophageal sulcus on the right side, and thymic nonencapsulated parathyroid tissue on the left side.

The lesion, which was observed on the left in the scintigraphy, disappeared after the first operation, and serum parathyroid hormone and calcium levels were slightly lower after first operation. Furthermore, the ectopic adenoma suppressed all other normal glands but did not appear to suppress the thymic parathyroid tissue. Therefore, thymic nonadenomatous parathyroid tissue may have contributed to the hyperparathyroid condition in this case. Another case report described nonadenomatous unencapsulated parathyroid tissue as a cause of persistent primary hyperparathyroidism (5). The association of the ectopic parathyroid glands and the thymus may be due to their common embryologic origin from the pharyngeal pouch or common genetic abnormality. However, we cannot evaluate if the nonadenomatous thymic parathyroid tissue would be able to mantain the hypersecretion state if the ectopic adenoma was resected first.

Gamma probe can help surgeons to locate adenomas $(10,11)$. In the second operation of the case that we presented, we administered a low dose radiotracer, used the intraoperative gamma probe, successfully located the ectopic adenoma, and removed it without the need of frozen section to confirm it.

There may be more than one ectopic parathyroid lesion located in different places, as occurred in this case. Also, it must be kept in mind that there may be ectopic hypercellular parathyroid lesions in thymus rather than distinct adenomas. Careful histological examination is of paramount importance in resected thymus tissue. 
a $\mathbf{A}$

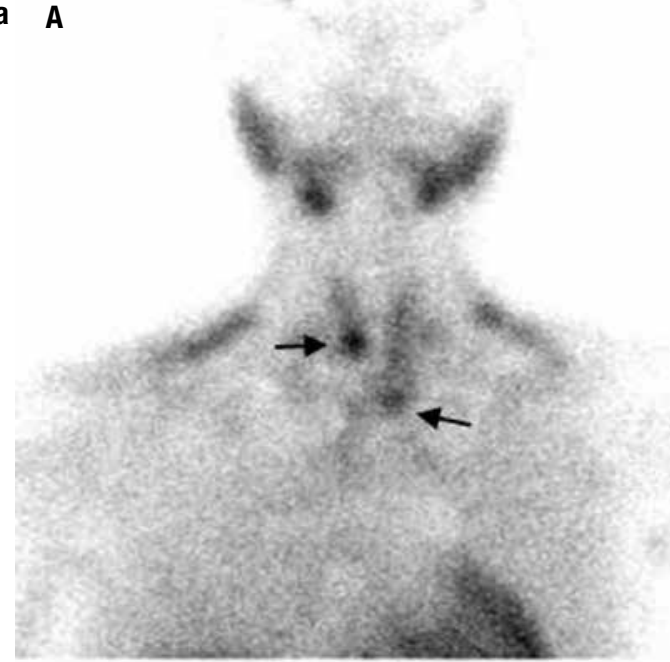

b

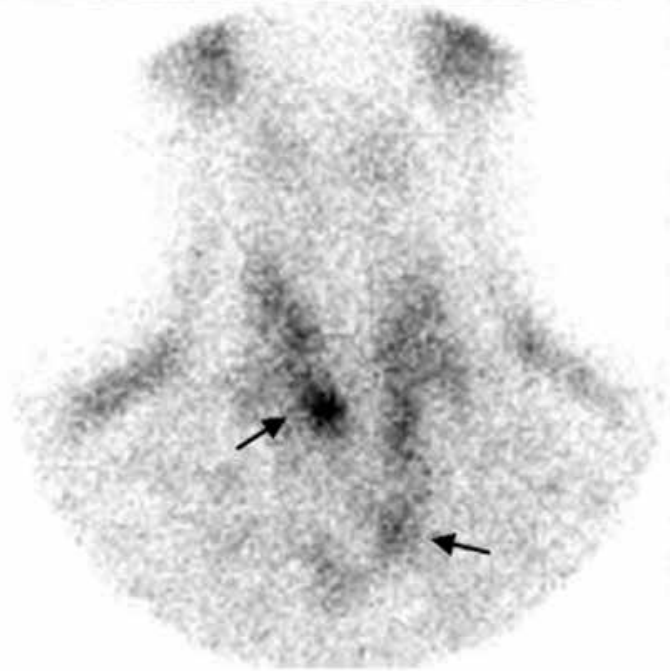

a $\mathbf{B}$
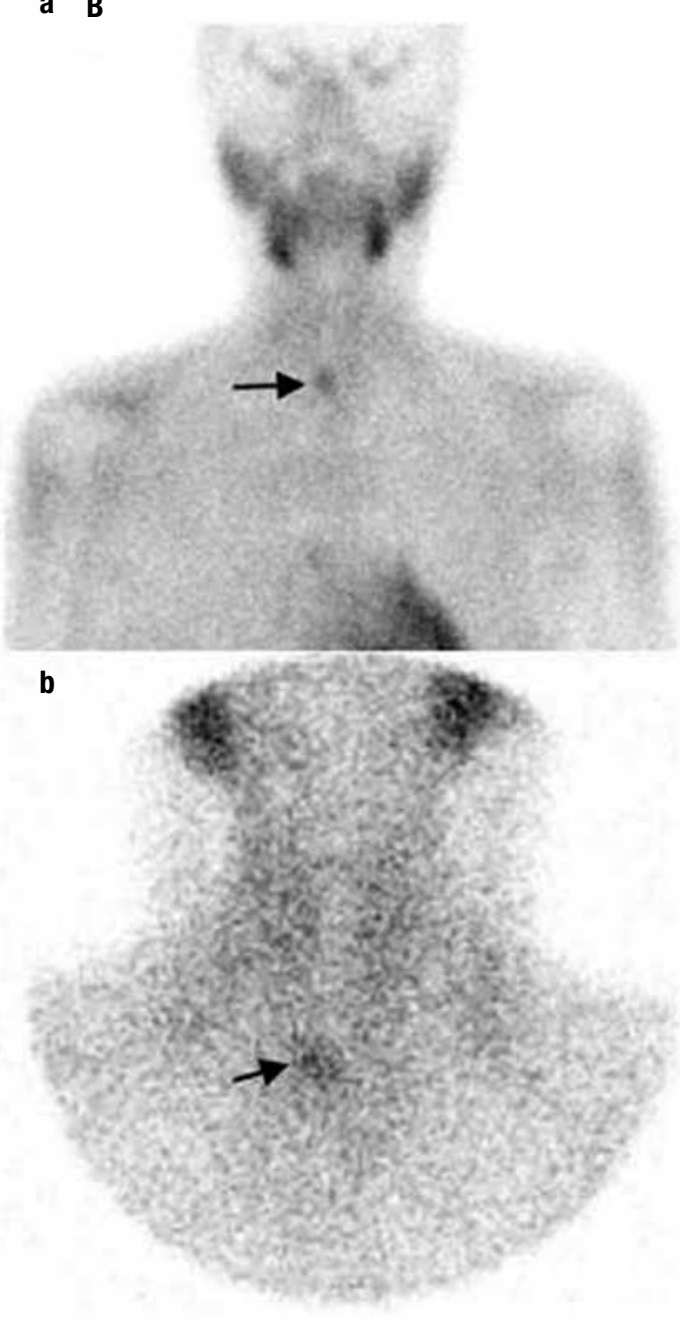

Figure 1. (A) Preoperative ${ }^{99 m}$ Tc-sestamibi dual phase parathyroid scintigraphy. Early (a) and delayed (b) phase images reveal two foci of persisted increased activity at the inferior tip of both lobes of the thyroid gland; however, pathological activity focus on the left is located more to the bottom than to the right. (B) Control ${ }^{99 m}$ TC-sestamibi dual phase parathyroid scintigraphy, 3 months after the first operation. Early (a) and delayed (b) phase images show a persistent focal uptake at the inferior part only in the right thyroid lobe.

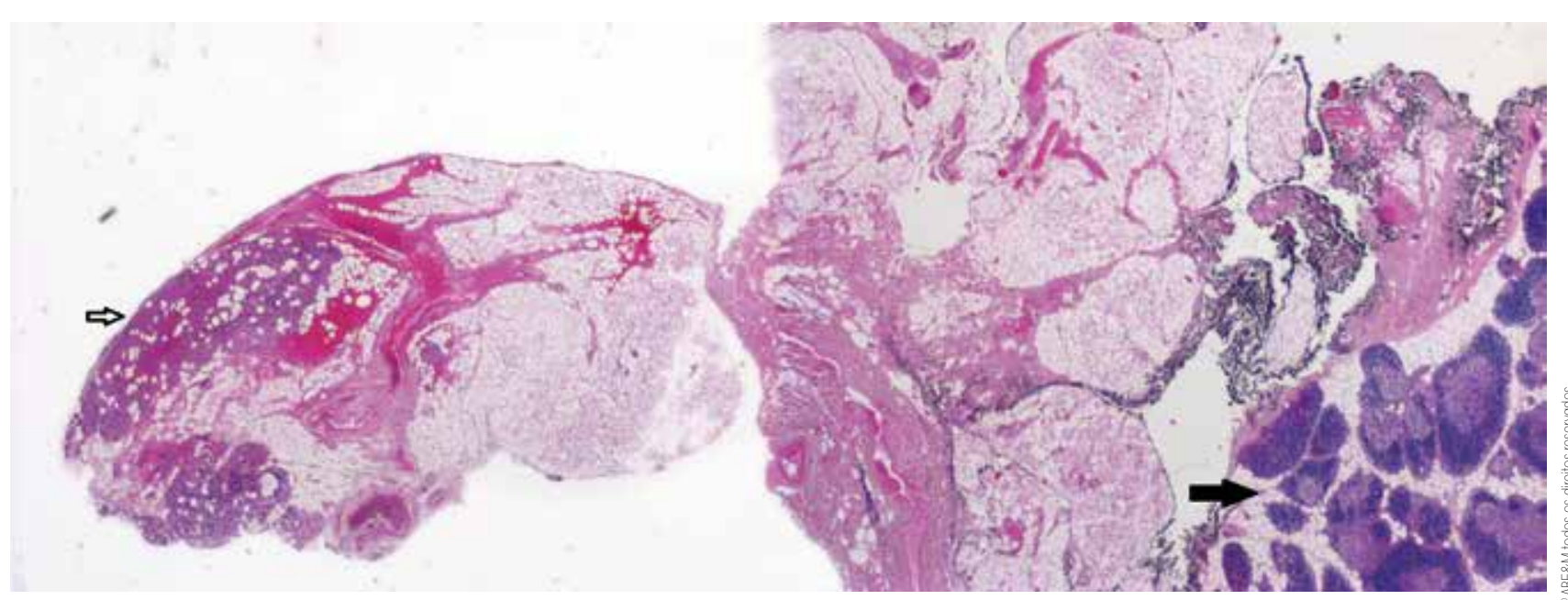

Figure 2. Microscopic view in the histopathological examination of thymus resection material. Nonadenomatous cellular parathyroid tissue in the thymus (H\&E, obj x 25) (Small, white arrow points to nonadenomatous cellular parathyroid tissue. Big, black arrow points to tyhmic tissue). 
Disclosure: no potential conflict of interest relevant to this article was reported.

\section{REFERENCES}

1. Udelsman R, Lin Z, Donovan P. The superiority of minimally invasive parathyroidectomy based on 1650 consecutive patients with primary hyperparathyroidism. Ann Surg. 2011;253(3):585-91.

2. Sosa JA, Powe NR, Levine MA, Udelsman R, Zeiger MA. Profile of a clinical practice: Thresholds for surgery and surgical outcomes for patients with primary hyperparathyroidism: a national survey of endocrine surgeons. J Clin Endocrinol Metab. 1998;83:2658-65.

3. Pattou $F$, Huglo $D$, Proye $C$. Radionuclide scanning in parathyroid disease. Br J Surg. 1998;85:1605-16.

4. Mendoza V, Ramírez C, Espinoza AE, González GA, Peña JF, Ramírez ME, et al. Characteristics of ectopic parathyroid glands in 145 cases of primary hyperparathyroidism. Endocr Pract. 2010;16(6):977-81.

5. Wei JP, Tippins RB, Rao RN, Burke GJ, Mansberger AR Jr. Nonadenomatous thymic unencapsulated parathyroid tissue as a cause of persistent primary hyperparathyroidism. South Med J. 1994;87(12):1264-8.

6. Hindié $E$, Ugur $O$, Fuster $D, O^{\prime}$ Doherty $M$, Grassetto $G$, Ureña $P$, et al. Parathyroid Task Group of the EANM. 2009 EANM parathyroid guidelines. Eur J Nucl Med Mol Imaging. 2009;36(7):1201-16.

7. Mariani G, Gulec SA, Rubello D, Boni G, Puccini M, Pelizzo MR, et al. Preoperative localization and radioguided parathyroid surgery. J Nucl Med. 2003;44(9):1443-58.

8. Johnson NA, Tublin ME, Ogilvie JB. Parathyroid imaging: technique and role in the preoperative evaluation of primary hyperparathyroidism. AJR Am J Roentgenol. 2007;188(6):1706-15.

9. Nguyen BD. Parathyroid imaging with Tc-99m sestamibi planar and SPECT scintigraphy. Radiographics. 1999;19(3):601-614; discussion 615-6.

10. Pitt SC, Panneerselvan R, Sippel RS, Chen H. Radioguided parathyroidectomy for hyperparathyroidism in the reoperative neck. Surgery. 2009;146(4):592-9.

11. Ikeda Y, Takayama J, Takami H. Minimally invasive radioguided parathyroidectomy for hyperparathyroidism. Ann Nucl Med. 2010;24(4):233-40. 